\title{
Model lipid bilayers as sensor bionanomaterials for characterization of membranotropic action of water-soluble substances
}

\author{
O.V.Vashchenko ${ }^{1}$, N.A.Kasian ${ }^{1}$, R.Ye.Brodskii ${ }^{2}$, \\ L.V.Budianska ${ }^{1}$, D.S.Sofronov ${ }^{3}$, L.N.Lisetski ${ }^{1}$ \\ ${ }^{1}$ Institute for Scintillation Materials, STC "Institute for Single Crystals", \\ National Academy of Sciences of Ukraine, \\ 60 Nauky Ave., 61072 Kharkiv, Ukraine \\ ${ }^{2}$ Institute for Single Crystals, STC "Institute for Single Crystals", \\ National Academy of Sciences of Ukraine, \\ 60 Nauky Ave., 61072 Kharkiv, Ukraine \\ ${ }^{3}$ SSI "ISC", National Academy of Sciences of Ukraine, \\ 60 Nauky Ave., 61072 Kharkiv, Ukraine
}

Received April 19, 2018

\begin{abstract}
Model phospholipid membranes are considered as sensor bionanomaterials to characterize water-soluble drugs of kosmotropic and chaotropic nature. Effects of kosmotropic agent dimethylsulfoxide (DMSO) and chaotropic tilorone on 1,2-dipalmitoylphosphatidylchoine multibilayer membranes were studied by differential scanning calorimetry and Fourier-transformed infrared spectroscopy. Tilorone and DMSO, water soluble hydrophilic substances, induced opposite shifts of membrane main phase transition temperatures $\Delta T_{m}$, which were positive for DMSO (as a kosmotropic dopant) and negative for chaotropic tilorone. For both dopants, dependences of $\Delta T_{m} v s$. dopant concentration $c$ were obtained and fitted by an analogue of the Freundlich equation of adsorption, $\Delta T_{m}=k c^{1 / n}$. A model has been proposed describing the action of hydrophilic dopants on lipid bilayer in terms of additional lateral pressure $P(c)$, which is positive for kosmotropes and negative for chaotropes. Applying the Clapeyron-Clausius equation to establish the character of $\Delta T_{m}(c)$ relation, power-law dependence was obtained, which was in good agreement with our experimental data. From comparison with literature data on Langmuir monolayers of similar systems, it was noted that the same power law relations could describe both phase transition temperature shifts and pressure-area dependences as function of dopant concentration.
\end{abstract}

Keywords: kosmotropes, chaotropes, model lipid membranes, phenomenological model, differential scanning calorimetry.

Модельные фосфолипидные мембраны рассмотрены как сенсорные бионаноматериалы для характеризации водорастворимых лекарственных веществ космотропной и хаотропной природы. Методами дифференциальной сканирующей калориметрии (ДСК) и Фурье-ИК-спектроскопии изучено действие диметилсульфоксида (ДМСО) и тилорона на мультибислойные мембраны 1,2-дипальмитоилфосфатидилхолина (ДПФХ). Тилорон и ДМСО, водорастворимые гидрофильные вещества, сдвигали температуру основного фазового перехода $\Delta T_{m}$ мембраны ДПФХ в противоположные стороны: положительную для космотропного ДМСО и отрицательную - для хаотропного тилорона. Для обеих 
добавок получены концентрационные зависимости $\Delta T_{m}(c)$ и предложена их аппроксимация аналогом уравнения Фрейндлиха для адсорбции $\Delta T_{m}=k c^{1 / n}$. Предложена модель, описывающая действие гидрофильных добавок на липидный бислой в терминах добавочного латерального давления $P(c)$, положительного для космотропов и отрицательного для хаотропов. Применение уравнения Клаузиуса-Клапейрона позволило установить степенной характер зависимости $\Delta T_{m}(c)$, в хорошем согласии с полученными данными ДСК. Сравнение с литературными данными по ленгмюровским монослоям для тех же систем позволило выявить одинаковый тип концентрационной зависимости как для $\Delta T_{m}$, так и для $\pi$-А изотерм.

Модельні ліпідні бішари як сенсорні біонаноматеріали для характеризації мембранотропної дії водорозчинних речовин. О.В.Ващенко, Н.О.Касян, Р.Е.Бродський, Л.В.Будянська, Д.С.Софронов, Л.М.Лисещький.

Модельні фосфоліпідні мембрани розглянуто як сенсорні біонаноматеріали для характеризації водорозчинних лікарських речовин космотропної та хаотропної природи. Методами диференціальної скануючої калориметрії (ДСК) та Фур'є-ІЧ-спектроскопії досліджено дію диметилсульфоксиду (ДМСО) та тілорону на мультишарові мембрани 1,2-дипальмітоїлфосфатидилхоліну (ДПФХ). Тілорон та ДМСО, водорозчинні гідрофільні речовини, зсували температуру основного фазового переходу $\Delta T_{m}$ мембрани ДПФХ у протилежні боки: позитивний для космотропного ДМСО та негативний для хаотропного тілорона. Для обох домішок отримано концентраційні залежності $\Delta T_{m}(c)$ та запропоновано ї апроксимацію за допомогою аналога рівняння Фрейндліха для адсорбції $\Delta T_{m}=k c^{1 / n}$. Запропоновано модель, яка описує дію гідрофільних домішок на ліпідний бішар у термінах додаткового латерального тиску $P(c)$, позитивного для космотронів та негативного для хаотропів. Застосування рівняння Клаузіуса-Клапейрона дозволило встановити степеневий характер залежності $\Delta T_{m}(c)$, у відповідності із отриманими даними ДСК. Порівняння із літературними даними щодо ленгмюровських моношарів для таких систем дозволило виявити однаковий тип концентраційних залежностей як для $\Delta T_{m}$, так і для $\pi$-А изотерм.

\section{Introduction}

Model phospholipid membranes, i. e. lyotropic phases of hydrated phospholipids with (multi)bilayer structure, are known to yield a specific response to introduction of drugs and other biologically relevant substances [1-8]. From this viewpoint, they can be considered as sensor bionanomaterials. A common approach to the problem of "drug-membrane interactions" consists in introduction of drugs or drug-like compounds to model phospholipid membranes and elucidation of their membranotropic effects using various instrumental methods, such as differential scanning calorimetry (DSC), spectroscopy, small-angle X-ray scattering, etc. The state-of-art is described in multiple recent papers (see, e.g., [9-14]). Generally, the effects are explained in terms of preferential interaction of the introduced substances with hydrophobic or hydrophilic moiety of phospholipid molecules. These interactions, with details specific for each dopant, affect the ordering of "heads" and "tails" of the host molecules in lyotropic liquid crystalline phases usually designated as $L_{\beta^{\prime}}, P_{\beta^{\prime}}$ and $L_{\alpha}$ (often described as "gel", "ripple" and "liquid crystal" phase, respectively) [15-18]. The ther- motropic transitions occurring in the order $L_{\beta^{\prime}} \rightarrow P_{\beta^{\prime}} \rightarrow L_{\alpha}$ are commonly called "pretransition" (at temperature $T_{p}$ ) and "main transition" (at $T_{m}$ ).

Despite a huge amount of the available experimental data, there are no generally accepted approaches that would allow prediction of the effect of a given dopant on phase transitions basing on some simple considerations. An attempt of such approach was made in our recent paper [19], where we analyzed the effects of different molecular parameters of a number of dopants upon changes in the temperature of the main phase transition. These parameters included the lipophilicity coefficient, $\log P$, molecular volume and surface area, dipole moment, molecular anisometry determined from geometry of the molecular models, fractions of the polar and non-polar parts of the dopant molecule, etc. In many cases, certain relationships were established, which, for groups of molecules with similar structure, yielded linear correlation coefficients $r$ up to 0.9 .

It should be noted that in most papers main attention was paid to hydrophobic drug-membrane interactions. However, interactions between polar membrane surface and hydrophilic dopants can substantially 


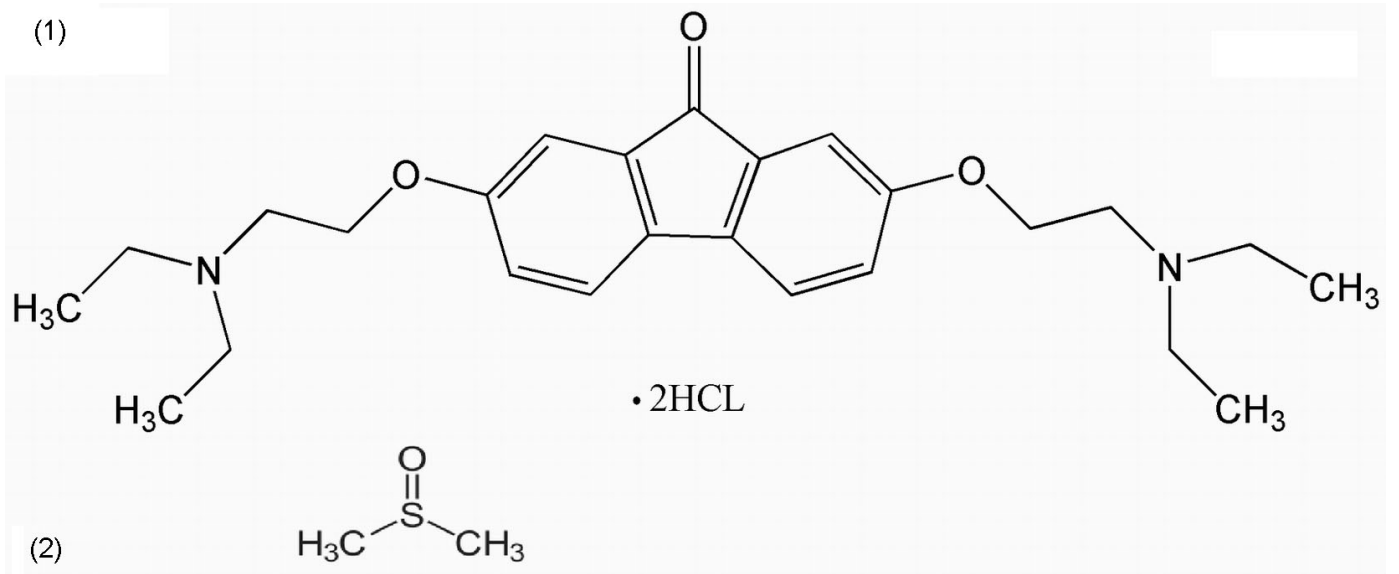

Fig. 1. Chemical structure of the dopants used, tilorone dihydrochloride (1) and dimethylsulfoxide, DMSO (2).

contribute to the total effect. In this paper, we consider membranotropic effects of hydrophilic substances introduced into the phospholipid membranes accounting for their chaotropic or kosmotropic nature.

The terms "chaotrope" and "kosmotrope" was first introduced for ions distinguished by their efficiency at protein precipitation or solubilization (Hoffmeister series) [20]. Then, "kosmotropicity/chaotropicity" conseption were expanded from ions to a wide group of substances, and their influence onto water properties had been carefully studied [21-25]. DNA melting temperature was also established to be affected by kosmotropic and chaotropic agents in opposite manner [26]. The general biological significance of the phenomenon has still been under consideration [24, 27-30] within the framework of conception of indirect Hoffmeister effects via water structure changes [26, 31, 32].

Lipid bilayers are also influenced by Hoffmeister effects. Indeed, their surface is abundant in highly hydrated phosphate groups, and hydrophobic interactions in the layer are strong. A number of important regularities concerning membranotropic action of kosmotropes and chaotropes were noted in [33]. For instance, kosmotropic dopants favor formation of the high-temperature inverted hexagonal phase (HII), the low-temperature lamellar crystalline $\left(L_{c}\right)$ and gel $\left(L_{\beta}\right.$ or $\left.L_{\beta^{\prime}}\right)$ phases at the expense of the lamellar liquid-crystalline phase $\left(L_{\alpha}\right)$. The effect is accompanied by a decrease in the half-width of the melting peak as well as increased hysteresis [34]. On the contrary, chaotropic dopants expand the existence range of $L_{\beta}$ phase not only in monolipid membranes but also in lipid mix- tures [35, 36]. The interactions of both chaotropic anions and strongly kosmotropic cations with zwitterionic lipids were found to be related to nearly unhindered lipid mobility in the acidic $p H$ range [37]. The magnitude of the solute effect is proportional to the hydration difference of the adjacent lipid phases and inversely proportional to the transition latent heat [33]. Linear correlation between the shifts of $L_{\beta^{\prime}} \rightarrow L_{\alpha}$ phase transition temperatures $\left(\Delta T_{m}\right)$ and the values of cationic radii was shown in our previous work [38]. It was noted that $\Delta T_{m}$ changed the sign (from positive to negative) at a certain critical ionic radius which divides kosmotropic and chaotropic cations of IA subgroup. At the same time, for IB subgroup cations, larger effects were observed under similar values of ionic radii, which was probably due to higher electron density [18, 38].

There are a number of models describing membranotropic Hoffmeister effects. In [39, 40], a two-domain model was suggested for analysis of the effects of salts and uncharged solutes on protein and nucleic acid processes. A model describing the effects of salts as osmotic stress was proposed in [41]. In [33], equation for $T_{m}$ as function of solute concentration was derived from general thermodynamic consideration for a quantitative characterization of Hoffmeister effects.

In the present work dimethylsulfoxide (DMSO) and tilorone [42] were chosen as kosmotropic and chaotropic dopants, and their effects on $\Delta T_{m}$ were explored by means of differential scanning calorimetry (DSC). A model is proposed to link $\Delta T_{m}$ and dopant concentration which is based on the hypothesis that the action of the dopant on the membrane can be described by additional 
a)

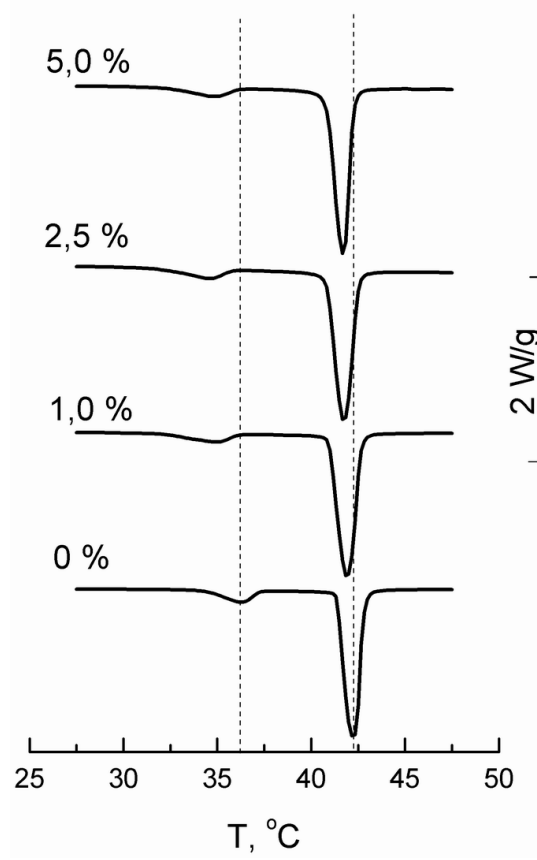

b)

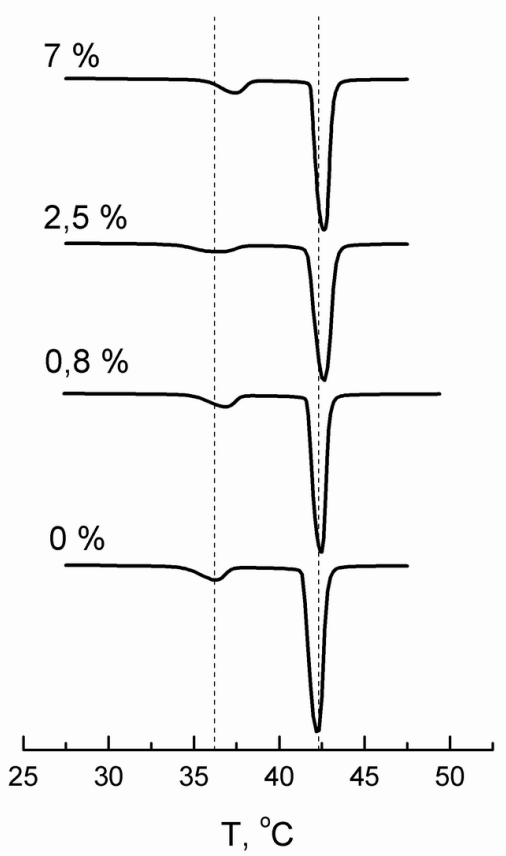

Fig. 2. Normalized DSC-profiles (heating) of DPPC membranes with tilorone (a) and DMSO (b). Dopant concentrations ( $\% \mathrm{w} / \mathrm{w}$, relatively to dry DPPC) are marked. Dotted lines are guides for eyes showing the temperatures of pre- and main transitions of the pure DPPC membrane.

effective lateral pressure $P_{\text {eff }}$ (positive for kosmotropes and negative for chaotropes).

\section{Materials and methods}

Materials. L- $\alpha$-dipalmitoylphosphatidylcholine (DPPC, purity $99.9 \%$ ) was purchased from Avanti Polar Lipids (USA), dimethyl sulfoxide, (purity $99.5 \%$ ) and tilorone (2,7-bis[2-(diethylamino)ethoxy]-9-fluoreno ne dihydrochloride) were obtained from Fluka (Switzerland) and Interchem (Ukraine), respectively. Fig. 1 depicts structural formulae of the dopants studied. Multilamellar lipid membranes of DPPC with dopants were prepared as described in [43] with water content $60 \% \mathrm{w} / \mathrm{w}$.

DSC measurements were performed using a microcalorimeter Mettler DSC 1 with STARe software version 11.00. The thermal scans were obtained in heating and cooling modes at $2 \mathrm{~K} / \mathrm{min}$ in the 20 to $55^{\circ} \mathrm{C}$ range. Temperatures at the maximum of the heat flow were taken as the transition temperature $\left(T_{p}\right.$ for the $L_{\beta^{\prime}} \rightarrow P_{\beta^{\prime}}$ and $T_{m}$ for the $P_{\beta^{\prime}} \rightarrow L_{\alpha}$ transitions) as well as corresponding enthalpies. Each experiment was repeated three times to attest the reproducibility of results. Experimental errors was $0.1^{\circ} \mathrm{C}$ for $T_{m}$ and $T_{p}$ values and $10 \%$ for enthalpy values.
FTIR mesurements of the lipid membranes containing drugs were performed for samples extracted from pans after DSC experiments using a Spectrum One spectrophotometer (Perkin-Elmer). Water solutions of tilorone, DMSO and (DMSO+tilorone) mixtures were also examined. The samples were placed between ZnSe plates by "crushed drop" method and scanned in the range $4000-400 \mathrm{~cm}^{-1}$ at room temperature (corresponding to $L_{\beta^{\prime}}$-phase of DPPC membrane). After baseline substraction, the spectra of lipid membranes were normalized by optical density at $1220 \mathrm{~cm}^{-1}$.

\section{Experimental}

The representative DSC scans of DPPC membranes containing gradually increasing amounts of tilorone and DMSO are shown at Fig. 2. Changes of the DSC profiles evidence dopant sorption onto the lipid bilayer. Due to their hydrophilic nature (see Table), both dopants probably interact mainly with the membrane polar surface. Such interaction could be considered as adsorption, where hydration forces are of great concern [44]. As one can see, the dopants have opposite effects on the membrane melting temperature $\left(T_{m}\right)$, namely, decrease in the presence of tilorone and increase for DMSO. Tilorone, unlike DMSO, induces progressive dis- 

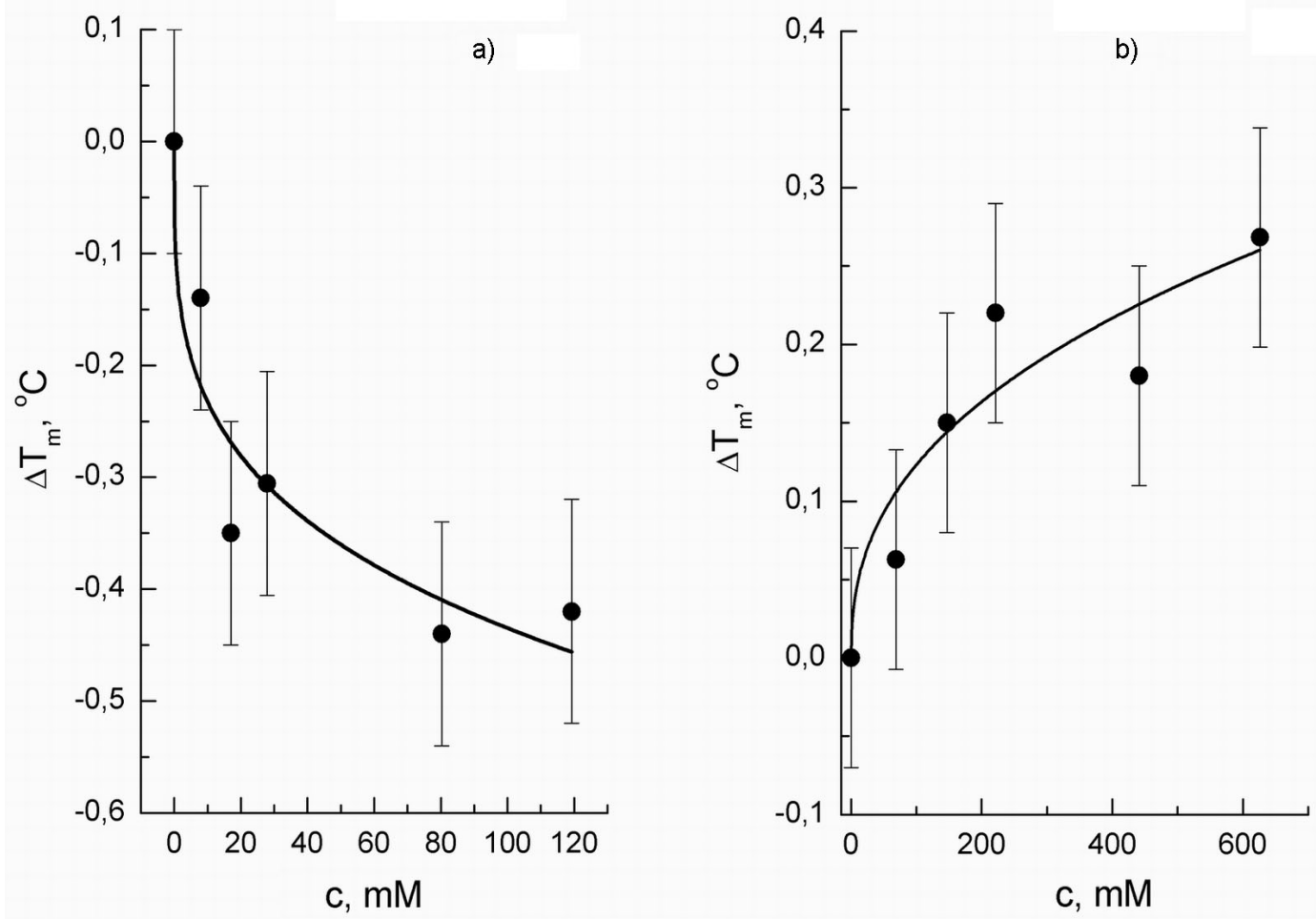

Fig. 3. Concentration dependence of $\Delta T_{m}$ in the presence of tiolorone (a) and DMSO (b). Dots experimental data, lines - approximation by Freundlich equation.

appearance of the pre-transition $\left(T_{p}\right)$. Herewith, the observed enthalpy changes under drugs sorption remain within experimental error.

Basing on the DSC data, the $T_{m}$ shift values $\left(\Delta T_{m}\right)$ were plotted as a function of the dopant concentration in water phase, Fig. 3. Assuming that $\Delta T_{m}$ is proportional to amount of dopant adsorbed on membrane surface, the experimental data could be fitted reasonably by an analogue of the Freundlich equation of adsorption [45]:

$$
\Delta T_{m}=k c^{1 / n},
$$

where $\Delta T_{m}$ is the dopant-induced shift of the membrane melting temperature, which is believed to be proportional to specific adsorption, $c$ is the dopant concentration in the water solution $(\mathrm{mM})$, and $k, n$ are phenomenological parameters.

The obtained adsorption parameters are shown in Table. Parameter $k$ reflects the $\Delta T_{m}$ value at unit dopant concentration and can be considered as a qualitative characteristic of the membranotropic action. It is negative for chaotropic dopants and positive for kosmotropic ones. Parameter $1 / n$ corresponds to the slope of $\Delta T_{m}(c)$ dependence in $\log$-log scale. In our experiment, $|k|$ appears
Table 1. Parameters of Freundlich fitting (Eq. 1) of $\Delta T_{m}(c)$ dependences for tilorone and DMSO in DPPC membrane

\begin{tabular}{|c|c|c|c||}
\hline Substance & $1 / n$ & $k$ & $\begin{array}{c}\text { Adj. R-square of } \\
\text { the fit curve }\end{array}$ \\
\hline Tilorone & 0.27 & -0.12 & 0.87 \\
\hline DMSO & 0.41 & 0.02 & 0.79 \\
\hline
\end{tabular}

higher for tilorone, whereas $1 / n$ is larger for DMSO.

FTIR technique provides an effective tool for probing hydration changes of lipid membranes by monitoring antisymmetric stretching band of phosphate group at $1200-1250 \mathrm{~cm}^{-1}$. Spectral components of this peak at $\sim 1220 \mathrm{~cm}^{-1}$ and $\sim 1240 \mathrm{~cm}^{-1}$ are assigned to hydrated and "free" phosphate groups, respectively [46]. It was shown [47] that DMSO enhances the contribution of "free" phosphate groups with respect to the hydrated phosphate groups of DPPC. It is believed that DMSO-induced decrease of lipid membrane hydration is responsible for enhanced thermal stability of the gel phase [48-53]. Our FTIR data evidenced that tilorone has no effect on hydration of DPPC phosphate group (Fig. 4). Meanwhile for the mixture "tilorone + DMSO" we 


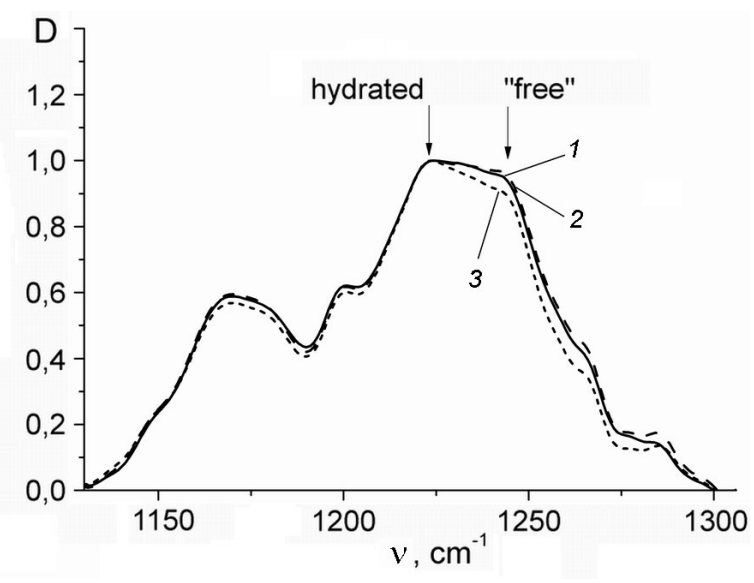

Fig. 4. FTIR spectra of antisymmetric stretching bands of DPPC phosphates at room temperature (gel phase): 1 - no dopants, 2 - tilorone, 3 - "'tilorone + DMSO'".

observed decreasing of the absorption at $1240 \mathrm{~cm}^{-1}$ as compared to $1220 \mathrm{~cm}^{-1}$, which corresponds to the increase of phosphate group hydration (Fig. 4, curve 3). So, joint drug application caused qualitatively different effect on DPPC membrane hydration. Taking into account the absence of any additional bands or their modification in FTIR spectra of "tilorone + DMSO" water solutions (data are not shown), the effect reported could not be attributed to direct tilorone-DMSO interaction.

\section{Phenomenological model of $" \Delta T_{m}-c "$ relation}

The main phase transition in the membrane is generally thought to be related to conformation disordering of the hydrophobic "tails" of the lipid molecules. The inverse effect, i.e., straightening of the tails, can be described in terms of packing - it results from pressure on a given molecule exerted by its neighbors, or, in other words, from the lack of free volume. The transition temperature $T_{m}$ would then be sensitive to the lateral pressure - it will increase under compression and decrease under stretching of the membrane.

The local pressure in the membrane can be affected by introduction of the dopant molecules. Indeed, kosmotropic dopants increase the local pressure, compacting the lipid molecules and decreasing the area per lipid molecule. Chaotropic molecules act in the opposite way. Changes in molecular area are directly correlated with lipid hydration in planar bilyers, which contributes to the membrane lateral pressure [54]. Interrela- tion between chain packing and hydration has been clearly demonstated in a recent paper [55] by means of molecular dynamic simulation. Thus, the action of the dopant on the membrane can be described by additional effective lateral pressure $P_{\text {eff }}$ (positive for kosmotropes and negative for chaotropes).

Let us consider the Clapeyron-Clausius equation, which relates the temperature of transition with pressure, for the membrane, i.e., for a two-dimensional case. Reducing the conventional three-dimensional equation by the membrane thickness, we obtain

$$
\frac{d T_{m}}{d P}=\frac{T_{m}\left(a_{2}-a_{1}\right)}{q},
$$

where $a_{1,2}$ are the molecular areas before and after the phase transition, $q$ is the transition enthalpy, and the effective pressure of the dopant $P_{\text {eff }}$ is taken as pressure $P$.

To obtain the transition temperature $T_{m}$ as function of the dopant concentration $c$, we must know the form of $P_{e f f}(c)$. The relationship between the lateral pressure and molecular area in membranes was studied experimentally for Langmuir films at different concentrations of various dopants [56]. The results obtained in that work can be interpreted in terms of the above-introduced effective pressure. If different lateral pressures should be applied to maintain the same molecular area in the doped and undoped membrane, the difference between these pressures would be equal to the effective pressure caused by the introduced dopant. In [56], the dopants introduced to the membrane were chaotropic ("loosening"), so, $P_{\text {eff }}(c)<0$. In that work, the dependence of effective pressure vs. dopant concentration can be well approximated by power law which could be written down as

$$
P_{e f f}=B c^{\beta}
$$

where $c$ is molar concentration of the dopant in water solution.

From Figs. 1, 2 of the same paper it can be seen that the difference of molecular areas $\left(a_{2}-a_{1}\right)$ in the phase transition does not change significantly with different dopants and concentrations. It is also known that the transition enthalpy is only weakly changed upon dopant addition. We will assume these values to be constant in the Clapeyron-Clausius equation.

We obtain

$$
\ln \frac{T_{m}}{T_{m 0}}=\frac{\left(a_{2}-a_{1}\right)}{q} P_{e f f}
$$


where $T_{m 0}$ is the transition temperature in the undoped membrane. Both literature data and our experiments (Figs. 1, 2) suggest that the change $\Delta T_{m}$ in the transition temperature is much smaller than $T_{m}$. So, we can assume

$$
\ln \left(T_{m} / T_{m 0}\right)=\ln \left(1+\Delta T_{m} / T_{m 0}\right) \approx \Delta T_{m} / T_{m 0}
$$

and

$$
\Delta T_{m} \approx T_{m 0} \frac{\left(a_{2}-a_{1}\right)}{q} P_{e f f}
$$

or, finally,

$$
\Delta T_{m}(c) \approx\left(T_{m 0}\left(a_{2}-a_{1}\right) q B\right) \cdot c^{\beta} .
$$

Experimental results obtained in the present work show that, in fact, the dependences $\Delta T_{m}(c)$ can be well approximated by the power law.

Thus, the proposed model describing the dopant action on the membrane as additional lateral pressure connects the results of two different experiments - DSC measurements of the transition temperature that were carried out in the present work, and experiments on Langmuir films presented in [56]. In other words, knowing the dependence $P_{\text {eff }}(c)$, we can predict, using the proposed model, the character of $\Delta T_{m}(c)$ for a given membrane and dopant, or vice versa - we can determine $P_{\text {eff }}(c)$ from $\Delta T_{m}(c)$, measured in the calorimetric experiment.

In the present study, the values obtained for the power index $1 / n$ of function $\Delta T_{m}(c) \infty c^{1 / n}$ (see Eq. 1) is 0.41 for DMSO and 0.23 for tilorone (see Table). Similar power-low relation, $P(c)=B c^{\beta}$, was obtained experimentally for lateral pressure $P(c)$ in DPPC monolayers doped with sodium salts [56], were $\beta \geq 0.5$.

Let us consider the additional effective pressure $P_{\text {eff }}(c)$ at the microscopic level. If the dopant concentration is low, and each molecule acts upon the membrane independently, then each molecule will decrease (for kosmotropic dopant) or increase (for chaotropic dopant) the membrane area by the value $\sigma$, which depends upon the dopant nature. To make signs of pressure values natural, we put $\sigma>0$ for kosmotropic dopants and $\sigma<0$ for chaotropic ones, i.e., we consider $\sigma$ as the measure of decreasing of the membrane area; thus, $\sigma$ can be considered as a certain measure of kosmotropicity.

At surface concentration of molecules $c_{m}$ per unit area, the relative change in the membrane surface area with respect to undoped membrane will be equal to $\Delta S / S=$ $\sigma c_{m} S / S=\sigma c_{m}$. The effective pressure is proportional to relative contraction, $P_{\text {eff }}=$ $K \sigma c_{m}$, where $K$ is the coefficient of relative area decrease.

The coefficient $K$ is determined by mechanical properties of the membrane, and $\sigma-$ by interaction of each individual molecule with the membrane. At low concentrations, their concentration dependence can be neglected. Thus, power dependence of $P_{\text {eff }}$ on concentration $c$ is related to the power dependence $c_{m}(c)$, i.e., to the power form of the adsorption law. Such dependence is characteristic for Freundlich adsorption. We can assume such form of adsorption to be realized in the system under our study, which is supported by DSC data (see Table 1).

The values $K$ and $\sigma$ could be estimated on the basis of literature data. Indeed, $k$ obtained from [56] as a slope of $\pi$-A isotherm in liquid-condensed phase is $\sim 0.15$ for DPPC. Substitution of $0.5 \mathrm{M} \mathrm{Nal}$ for water subfase slightly changes $K$, but leads to an increase in the lipid cross-area by the value of $\sim 2 \AA^{2}$, which is nearly independent on lateral pressure. Taking into account the corresponding lipid:ion molar ratio in fully hydrated DPPC multibilayers [38], we can estimate the upper limit of $\sigma$ as $6 \AA^{2}$. Note that relative changes in lipid areas caused by $0.5 \mathrm{M} \mathrm{NaBr}$ and $0.5 \mathrm{M} \mathrm{Nal}$ $\left(\Delta A^{\mathrm{Br}} / \Delta A^{\mathrm{I}}=0.25 \pm 0.05\right)$ are of the same order with oppite changes in $\Delta T_{m}$ for these salts $(0.33 \pm 0.15)$ [38].

Finally, let us compare Eq. (2) with the equation for $\Delta T_{m}$ obtained in [33] from general thermodynamic principles. In that work, the following equation was derived:

$$
\frac{d T_{m}}{d \tilde{c}}=\frac{R T_{m}^{2}}{H}\left(x_{2}-x_{1}\right)\left(1-\frac{\tilde{c}_{L}}{\tilde{c}}\right) .
$$

Here $\tilde{c}_{L}, \tilde{c}$ are dopant concentrations in the membrane and in solution, respectively, expressed as the number of dopant molecules per one molecule of water, $x$ is the hydration degree, i.e., number of water molecules per one lipid molecule in the membrane, $H$ is the molar transition enthalpy, $H=N_{A} q$.

The difference in the degree of hydration before and after the transition can be expressed as $x_{2}-x_{1}=\alpha\left(a_{2}-a_{1}\right)$, where $\alpha$ is the number of water molecules per unit area of the membrane. 
The molar concentration $c$ as used here can be expressed as $c=p \tilde{c}$, where $\tilde{c}$ is the concentration in moles per mole of water [33], and $\rho$ is the molar density of water in mol/l. Thus, the equation obtained in [33] can be expressed as

$$
\frac{d T_{m}}{k T_{m}\left(1-\frac{\tilde{c}_{L}}{\tilde{c}}\right) \frac{\alpha}{\rho} d c}=\frac{T_{m}\left(a_{2}-a_{1}\right)}{q} .
$$

Comparing this equation with the Clapeiron-Clausius equiation (Eq. 2), we see that they would be identical under condition

$$
P_{e f f}^{\prime}(c)=k T_{m}\left(1-\frac{\tilde{c}_{L}}{\tilde{c}}\right) \frac{\alpha}{\rho} .
$$

From $P_{e f f}(c)=K \sigma c_{m}$, we obtain for the surface concentration

$$
c_{m}^{\prime}(c)=\frac{k T_{m}}{K \sigma}\left(1-\frac{\tilde{c}_{L}}{\tilde{c}}\right) \frac{\alpha}{\rho} .
$$

From the definitions of $c_{m}, \tilde{c}_{L}$

$$
c_{m}=\tilde{c}_{L} x \alpha,
$$

where the hydration degree $x$ is taken in the phase under consideration. Expressing $\tilde{c}_{L}$ from (9) and substituting it into (8), we obtain

$$
c_{m}^{\prime}(c)=\frac{k T_{m}}{K \sigma}\left(1-\frac{\rho c_{m}}{x \alpha c}\right) \frac{\alpha}{\rho} .
$$

For $c_{m}(c)$ that are solutions of Eq. 10, Eq. 5 (obtained in [33]) and Eq. 2 appear to be identical.

For the sake of simplification, Eq. 10 can be re-written in the form:

$$
c_{m}^{\prime}(c)=a\left(1-b \frac{c_{m}(c)}{c}\right) .
$$

Here, we can assume that
$=\frac{k T_{m 0}}{K \sigma} \frac{\alpha}{\rho}=$ const,

it was noted above; $b=\frac{\rho}{x \alpha}$.

The solution of this equation has the form

$$
c_{m}=C \cdot c^{-a b}+\frac{a}{1+a b} c
$$

when $a b \neq-1, C$ is an arbitrary constant. Here $a b=\frac{k T_{m 0}}{K \sigma x}$ sign is in agreement with the sign of $\sigma$.
Let us determine the value of $C$. For the kosmotropes $(\sigma>0, a b>0)$, this value can be easily obtained from the natural boundary condition $c_{m}(0)=0$. Since for $a b>0$, $c^{-\mathrm{ab}} \rightarrow \propto$ at $c \rightarrow 0$, the only possible value of $C=0$. We obtain

$$
c_{m}=\frac{a}{1+a b} c \propto c,
$$

which, in fact, expresses the Henry's law. This is a characteristic adsorption law for small concentrations. For chaotropes, the boundary condition $c_{m}(0)=0$ can be satisfied by solutions with non-zero $C$, however, in practice (at least at low concentrations) only the linear dependence $c_{m}=\frac{a}{1+a b} c=-\frac{|a|}{1-\mid a b} c \propto c, \quad C=0$, would be realized. The value of $a b$ in this case should be less than $-1(|a b|>1)$.

One could note the above-mentioned relationship between dopant-induced changes in $T_{m}$ and additional pressure in lipid bilayers was implicitly noted in literature, e,g., where $T_{m}$ lowering was accompanied by higher bilayer compressibility [57]. A correlation between dopant-induced $T_{m}$ shifts in DPPC bilayers and changes in pressure-area diagrams in DPPC Langmuir monolayers was also noted in our earlier paper [58].

Thus, we have found that our Eq. 2 matches with equations obtained in [33] when adsorption of the dopant obeys the Henry's law (Eq. 11). The authors of [33] stressed that their equation could be valid only for small dopant concentrations, i.e., under the same conditions when Henry's law is valid, supporting the idea of equivalence of both equations. The Henry's law can be considered as a limiting approximation of the Langmuir's law for small concentrations. There is no such linear region in the Freundlich's law. However, the Freundlich law should be used when there are multiple centers with different binding energies that participate in the adsorption process. At small dopant concentrations, the linear dependence (i.e. Henry's law) is valid.

\section{Conclusions}

In DSC experiments, tilorone and DMSO were shown to exert opposite effects on DPPC membrane melting temperature (a decrease for tilorone and increase for DMSO). Considering tilorone and DMSO as examples, respectively, of chaotropic and kosmotropic dopants that are adsorbed on the membrane surface, concentration depend- 
ences of membrane melting temperature shift $\Delta T_{m}(c)$ were fitted by an analogue of the Freundlich equation of adsorption, $\Delta T_{m}$ $=k c^{1 / n}$. A model has been proposed describing the action of hydrophilic dopants on lipid bilayer in terms of additional lateral pressure $P(c)$, which is positive for kosmotropes and negative for chaotropes. This allowed us to apply the Clapeyron-Clausius equation in a modified two-dimensional form to establish the character of $\Delta T_{m}(c)$ relation. This relation was shown to be of power-law form (similar to the pressure vs. concentration dependences reported in literature for Langmuir monolayers), in good agreement with the experimental data.

Acknowledgements. The authors are sincerely grateful to SLC InterChem (Odessa, Ukraine) for collaboration.

\section{References}

1. M.Bloom, E.Evans, O.G.Mouritsen, Quart. Rev. Biophys., 24, 293 (1991).

2. R.Koynova, M.Caffrey, Biochim.Biophys. Acta, 1376, 91 (1998).

3. J.F.Nagle, S.Tristram-Nagle, Biochim.Biophys. Acta, 1469, 159 (2000).

4. H.Binder, Eur. Biophys. J., 36, 265 (2007).

5. C.Peetla, A.Stine, V.Labhasetwar, Mol. Pharm., 6, 1264 (2009).

6. R.Pignatello, T.Musumeci, L.Basile et al., J. Pharm. Bioallied.Sci., 3, 4 (2011).

7. H.Li, T.Zhao, Z.Sun, Rev.Anal.Chem., 37. DOI:10.1515/revac-2017-0012. (2017).

8. K.A.Riske, C.C.Domingues, B.R.Casadei et al., Biophys. Rev., 9, 649 (2017).

9. P.Viswanath, A.Aroti, H.Motschmann, E.Leontidis, J.Phys.Chem. B, 113, 14816 (2009).

10. C.Altunayar, I.Sahin, N.Kazanci, Chem.Phys. Lipids, 188, 37 (2015).

11. O.V.Vashchenko, Iu.L.Iermak, A.O.Krasnikova, L.N.Lisetski, Biophysics, 60, 244 (2015).

12. G.D.Bothun, L.Boltz, Y.Kurniawan, C.Scholz, Colloids Surf. B Biointerf., 139, 62 (2016).

13. A.C.Alves, D.Ribeiro, C.Nunes, S.Reis, Biochim. Biophys. Acta, 1858, 231 (2016).

14. C.M.G.Da Silva, M.Franz-Montan, C.E.G.Limia et al., PloS One, 12(10). DOI: $10.1371 /$ journal.pone.0185828 (2017).

15. S.Tristram-Nagle, J.F.Nagle, Chem. Phys. Lipids, 127, 3 (2004).

16. C.Bourgaux, P.Couvreur, J.Control.Release, 190, 127 (2014).

17. Liquid Crystal Ordering and Nanostructuring in Model Lipid Membranes, ed. by V.A. Karachevtsev, Pan Stanford Publishing, Singapore (2016).

18. L.A.Bulavin, D.V.Soloviov, V.I.Gordeliy et al., Phase Trans., 88, 582 (2015).
19. A.O.Sadchenko, O.V.Vashchenko, N.A.Kasian, Functional Materials, 23, 230 (2016).

20. K.D.Collins, Methods, 34, 300 (2004).

21. G.E.Walrafen, J.Chem.Phys., 44, 3726 (1966).

22. H.D.B.Jenkins, Y.Marcus, Chem.Rev., 95, 2695 (1995).

23. K.D.Collins, Proc.Natl.Acad.Sci.USA, 92, 5553 (1995).

24. K.D.Collins, Biophys.Chem., 119, 271 (2006).

25. R.Zangi, J.Phys. Chem. B, 114, 643 (2010).

26. J.R.De Xammar Oro, J.Biol.Phys., 27, 73 (2001).

27. E.A.Galinski, Experientia, 49, 487 (1993).

28. T.H.Plumridge, R.D.Waigh, J.Pharm.Pharmacol., 54, 1155 (2002).

29. L.R.Singh, N.K.Poddar, T.A.Dar, J.Iran Chem.Soc., 8, 1 (2011).

30. D.Shukla, C.P.Schneider, B.L.Trout, $A d v$. Drug Deliv. Rev., 63, 1074 (2011).

31. S.Moelbert, B.Normand, P.De Los Rios, Biophys. Chem., 112, 45 (2004).

32. D.Russo, Chem. Phys. Lipids, 345, 200 (2008).

33. R.Koynova, J.Brankov, B.Tenchov, Eur. Biophys.J., 25, 261 (1997).

34. E.R.Pennington, C.Day, J.M.Parker et al., $J$. Therm. Anal. Calorim., 123, 2611 (2016).

35. S.Ohtake, C.Schebor, S.P.Palecek, J.J.de Pablo, Biochim. Biophys.Acta, 1713, 57 (2005).

36. S.Ohtake, C.Schebor, J.J.de Pablo, Biochim. Biophys. Acta, 1758, 65 (2006).

37. R.Zimmermann, D.Kuttner, L.Renner et al., J.Phys.Chem.A, 116, 6519 (2012).

38. O.V.Vashchenko, Yu.L.Ermak, L.N.Lisetski, Biophysics, 58, 515 (2013).

39. M.T.Record Jr, W.Zhang, C.F.Anderson, Adv. Protein Chem., 51, 281 (1998).

40. C.Wang, Y.Ge, J.Mortensen, P.Westh, J. Phys. Chem. B, 115, 9955 (2011).

41. A.Aroti, E.Leontidis, M.Dubois, T.Zemb, Biophys.J., 93, 1580 (2007).

42. S.Ekins, M.A.Lingerfelt, J.E.Comer, Antimicrob Agents Chemother, 62(2). DOI:10.1128/AAC.01711-17. (2018).

43. N.A.Kasian, V.A.Pashynska, O.V.Vashchenko, Mol. BioSyst., 10, 3155 (2014).

44. U.Essmann, L.Perera, M.L.Berkowitz, Langmuir, 11, 4519 (1995).

45. H.M.F.Freundlich, J.Phys.Chem.A, 57, 385 (1906).

46. C.Selle, W.Pohle, Biospectroscopy, 4, 281 (1998).

47. M.Ricci, R.Oliva, P.Del Vecchio, Biochim.Biophys.Acta, 1858, 3024 (2016).

48. P.Sassi, S.Caponi, M.Ricci, J.Raman Spectr., 46, 644 (2015).

49. W.F.Wolkers, H.Oldenhof, B.Glasmacher, Cryobiology, 61, 108 (2010).

50. L.M.Crowe, J.H.Crowe, D.Chapman, Arch.Biochem. Biophys., 236, 289 (1985). 
51. C.-Y.Cheng, J.Song, J.Pas et al., Biophys.J., 109, 330 (2015).

52. M.A.Kiselev, Crystallogr. Rep., 52, 529 (2007).

53. M.A.Kiselev, T.Gutberlet, P.Lesieur et al., Chem. Phys. Lipids, 133, 181 (2005).

54. D.Marsh, Biochim. Biophys. Acta, 1286, 183 (1996).

55. R.Hartkamp, T.C.Moore, C.R.Iacovella et al., J.Phys.Chem. B, 122, 3113 (2018).
56. A.Aroti, E.Leontidis, E.Maltseva, G.Brezesinski, J.Phys. Chem. B, 108, 15238 (2004).

57. R.Krivanek, P.Rybar, E.J.Prenner et al., Biochim. Biophys. Acta, 1510, 452 (2001).

58. L.N.Lisetski, O.V.Vashchenko, A.V.Tolmachev, K.B.Vodolazhskiy, Eur. Biophys.J., 31, 554 (2002). 